\title{
Fertility measures in Polish Black-and-White cattle. 3. Phenotypic and genetic correlations between fertility measures and milk production traits*
}

\author{
W. Jagusiak ${ }^{1}$ \\ Agricultural University of Cracow, \\ Department of Genetics and Animal Breeding \\ Al. Mickiewicza 24/28, 30-059 Kraków, Poland
}

(Received 13 December 2005; revised version 21 February 2006; accepted 5 July 2006)

\begin{abstract}
The objective of this research was to estimate phenotypic and genetic correlations between fertility and milk production traits. The following traits characterizing cow reproduction were studied: non-return rates till 56 and 72 days, age at first insemination, age at conception, calving interval, days open, days to first service, and service period. Data included reproductive traits of 42283 first-parity Black-and-White cows. Days open and calving interval were calculated for 25013 cows. The highest phenotypic correlation obtained between protein yield and days open amounted to 0.22 ; non-return rates showed the lowest phenotypic correlations with yield traits. All genetic correlations between reproductive traits and yield traits were unfavourable. The largest were found between yield traits and days open and calving interval (0.35-0.48), and the smallest for age at first insemination and non-return rate until day 72 (less than 0.1 ). Fat and protein content showed very small correlations with fertility traits; genetic correlations were also low except for non-return rates, which ranged from -0.55 (between fat content and non-return rate until day 56) to -0.24 (between protein content and non-return rate until day 72). The antagonistic genetic correlations between milk production and fertility traits show that selection for fertility is needed.
\end{abstract}

KEY WORDS: dairy cattle, fertility, genetic correlations, linear animal model

\section{INTRODUCTION}

Milk production and fertility traits are the main factors influencing profitability of dairy herds. Milk production of the individual cow depends on her ability to

\footnotetext{
* Supported by the State Committee for Scientific Research, Grant No. P06D 03827

${ }^{1}$ Corresponding author: e-mail: rzjagusi@cyf-kr.edu.pl
} 
become pregnant, and each lactation cycle is renewed by the next pregnancy. Until recently, breeding goals in most countries were based mainly on increased milk production per cow, and selection for only milk production led to reduced fertility. Abdallah and McDaniel (2000) reported a large, unfavourable genetic trend for days open in the Unites States after 1987.

Fertility traits are difficult to define. Some heifer fertility traits and interval fertility traits were described by Jagusiak $(2005 \mathrm{a}, \mathrm{b})$ in previous papers. Antagonistic correlations between milk production and fertility were reported in several studies. Hansen et al. (1983) and Roxström et al. (2001) reported similar unfavourable genetic correlations between $305 \mathrm{~d}$ yield traits and days open (0.320.34). Dematewewa and Berger (1998) estimated a slightly higher correlation between milk yield and days open (0.55). Genetic correlations obtained by Veerkamp et al. (2001) between yield and number of days to first service, calving interval and first conception rate were small and also unfavourable.

Better management in large herds may improve cow fertility, and despite unfavourable genetic correlations, phenotypic correlations are close to zero. Nebel and McGilliard (1993) found favourable environmental correlations between fertility and production. In large and high-producing herds, reproductive performance was higher due to better feeding and health management. In the Dutch herds with high production per cow, Windig et al. (2005) found a smaller average number of days to first service, but within herds, high-producing cows had a higher incidence of infertility.

Genetic correlations between production and fertility traits have not been estimated in population of Polish dairy cattle so far. Antagonistic relationships between these two groups of traits reported in the literature show that fertility traits should be included as part of the overall selection index, and should be genetically improved together with milk production traits. Genetic parameters of fertility measures in Polish Black-and-White cattle were published in the first and second parts of this study (Jagusiak, 2005a,b).

The purpose of this paper was to estimate phenotypic and genetic correlations between milk production traits and fertility measures needed to construct multiple traits selection indexes.

\section{MATERIAL AND METHODS}

The data set containing 42,283 records of cows was created, based on files of the Computing Centre in Olsztyn, according to rules described in detail by Jagusiak (2005a). Cows calved for the first time in 785 herds were classified into 2217 herd-year-season and 1657 herd-year subclasses. The following fertility 
measures were calculated for each cow: NR56 (non-return rate to 56th day), NR72 (non-return rate to 72th day), age at first insemination, age at conception, service period (days) (interval from first insemination to conception). Length of service period, age at first insemination, age at conception and non-return rates were computed for all cows, whereas yields were known for 42268 cows. Days to first service (interval from calving to first service), days open (interval from calving to conception), calving interval (days) (interval from calving to the next calving) were calculated for 25013 cows with second lactation completed. Each cow record contained $305 \mathrm{~d}$ milk, fat, protein yields, and fat and protein content in first lactation. Characteristics of data are shown in Table 1.

Table 1. Means and standard deviations of milk production and fertility traits

\begin{tabular}{lccc}
\hline Trait & $\mathrm{n}$ & $\overline{\mathrm{X}}$ & $\mathrm{SD}$ \\
\hline Milk, kg & 42.268 & 5605 & 1431 \\
Fat, kg & 42.268 & 231 & 63 \\
Fat, \% & 42.268 & 4.13 & 0.52 \\
Protein, kg & 42.268 & 181 & 48 \\
Protein, \% & 42.268 & 3.24 & 0.22 \\
NR $^{1} 56$ & 42.283 & 0.73 & 0.39 \\
NR $^{172}$ & 42.283 & 0.69 & 0.42 \\
Age at first insemination & 42.283 & 537.6 & 75.5 \\
Age at conception & 42.283 & 556.8 & 79.0 \\
Calving interval & 25.013 & 409.8 & 77.4 \\
Days open & 25.013 & 132.1 & 77.1 \\
Days to first service & 25.013 & 79.3 & 35.2 \\
Service period & 42.283 & 27.5 & 53.8 \\
\hline
\end{tabular}

${ }^{1}$ non-return rate

(Co)variance components of the fertility traits were estimated by restricted maximum likelihood (REML) (Misztal and Perez-Enciso, 1993), based on the following linear model:

$$
\mathbf{y}=\mathbf{X b}+\mathbf{Z Q g}+\mathbf{Z u}+\mathbf{e}
$$

where $\mathbf{y}$ is the vector of observations, $\mathbf{g}$ is the vector of fixed effects of genetic groups. Vector $\mathbf{b}$ is the vector of fixed effects, and for fertility measures consists of herd-year of calving and month of calving. Vector $\mathbf{b}$ for milk production traits consists of herd-year-season of calving and regression on age at calving. Vector $\mathbf{u}$ is the vector of additive animal genetic effects, $\mathbf{e}$ is the vector of residual error, and $\mathbf{X}, \mathbf{Z}$ and $\mathbf{Q}$ are coincidence matrices.

Matrix $\mathbf{G}=\mathbf{A}^{-1} \otimes \mathrm{G}_{0}$, where $\mathbf{A}^{-1}$ is the numerator relationship matrix and $\mathbf{G}_{0}$ the genetic (co)variance matrix between traits. Matrix $\mathbf{R}=\mathrm{I} \otimes \mathbf{R}_{0}$, where $\mathbf{R}_{0}$ is the residual (co)variance matrix between traits and $\otimes$ is the Kronecker product. 
Genetic groups were created according to Westell et al. (1988). Animals with unknown parents were assigned to genetic groups by birth year and percentage of Holstein-Friesian (HF) genes. Five groups for male and eight for female parents were created.

Variance components estimated for fertility measures in previous studies (Jagusiak, 2005a,b) were used as prior values to estimate (co)variance components using the multitrait animal model. (Co)variances between each milk production trait and fertility measures were estimated in three steps: 1 . (co)variances between milk production traits and age at first service and age at conception; 2. (co)variances between milk production traits and non-return rates; 3 . (co)variances between milk production traits and interval fertility measures. Phenotypic and genetic correlations between fertility measures and milk production traits were computed based on estimated (co)variances.

Standard errors of genetic correlation estimates were computed according to Dodenhoff et al. (1998).

\section{RESULTS}

Phenotypic correlations between yield and fertility traits

Phenotypic correlations between milk yield and fertility traits were in general small (Table 2). The highest coefficients of correlation were found for days open

Table 2. Genetic $\left(r_{\mathrm{g}}\right)$ and phenotypic $\left(\mathrm{r}_{\mathrm{p}}\right)$ correlations between milk yield and fertility traits and standard errors of the genetic correlations (SE)

\begin{tabular}{lccc}
\hline Trait & $\mathrm{r}_{\mathrm{p}}$ & $\mathrm{r}_{\mathrm{g}}$ & $\mathrm{SE}$ \\
\hline $\mathrm{NR}^{1} 56$ & -0.01 & -0.12 & 0.019 \\
$\mathrm{NR}^{1} 72$ & -0.02 & 0.05 & 0.018 \\
Age at first insemination & 0.05 & 0.05 & 0.013 \\
Age at conception & 0.10 & 0.08 & 0.025 \\
Calving interval & 0.21 & 0.35 & 0.065 \\
Days open & 0.21 & 0.35 & 0.066 \\
Days to first service & 0.11 & 0.29 & 0.033 \\
Service period & 0.11 & 0.10 & 0.007 \\
\hline
\end{tabular}

${ }^{1}$ see Table 1

and calving interval (0.21). Correlations for the remaining interval traits and age at conception were about 0.10 and correlation for age at first insemination was half that. Phenotypic correlations between milk yield and non-return rates were close to zero.

The phenotypic correlations of fat and protein yields with fertility traits were similar to those for milk yield (Table 3). The highest correlations were found for 
days open and calving interval ( 0.20 with fat and 0.22 with protein yield) and lower for days to first service and service period $(0.10)$. The correlations with age at first insemination and age at conception were slightly larger than in the case of milk yield ( 0.07 and 0.13 with fat yield, respectively), and the correlations of both fat and protein yields with non-return rates were close to zero.

Table 3. Genetic $\left(\mathrm{r}_{\mathrm{g}}\right.$ ) and phenotypic $\left(\mathrm{r}_{\mathrm{p}}\right.$ ) correlations between fat yield and fertility traits and standard errors of the genetic correlations (SE)

\begin{tabular}{lccc}
\hline Trait & $\mathrm{r}_{\mathrm{p}}$ & $\mathrm{r}_{\mathrm{g}}$ & $\mathrm{SE}$ \\
\hline $\mathrm{NR}^{1} 56$ & 0.01 & -0.15 & 0.022 \\
$\mathrm{NR}^{1} 72$ & -0.03 & -0.05 & 0.020 \\
Age at first insemination & 0.07 & 0.11 & 0.024 \\
Age at conception & 0.13 & 0.13 & 0.032 \\
Calving interval & 0.20 & 0.48 & 0.071 \\
Days open & 0.20 & 0.46 & 0.076 \\
Days to first service & 0.10 & 0.37 & 0.044 \\
Service period & 0.11 & 0.17 & 0.011 \\
\hline
\end{tabular}

${ }^{1}$ see Table 1

\section{Genetic correlations between yield and fertility traits}

The highest genetic correlations with milk yield were for days open and calving interval (0.35); and then for days to first service (0.29). Low positive genetic correlations were obtained between milk yield and service period, age at first insemination and age at conception ( 0.1 and less). The correlation of milk yield with NR56 was negative (-0.12), with NR72 it was positive but very low (0.05).

The genetic correlations with fat yield were in general higher than those with milk yield. The largest correlations were obtained for calving interval (0.48), days open (0.46) and days to first service (0.37); correlations for both age at first insemination and age at conception were positive and higher than 0.1 . The genetic correlations for non-return rates were negative and similar to thoses obtained for milk yield.

A similar pattern of genetic correlation was found for protein yield (Table 4).

Table 4. Genetic $\left(\mathrm{r}_{\mathrm{g}}\right)$ and phenotypic $\left(\mathrm{r}_{\mathrm{p}}\right)$ correlations between protein yield and fertility traits and standard errors of the genetic correlations (SE)

\begin{tabular}{lccc}
\hline Trait & $\mathrm{r}_{\mathrm{p}}$ & $\mathrm{r}_{\mathrm{g}}$ & $\mathrm{SE}$ \\
\hline $\mathrm{NR}^{1} 56$ & -0.05 & -0.09 & 0.028 \\
$\mathrm{NR}^{1} 72$ & -0.10 & -0.01 & 0.032 \\
Age at first insemination & 0.06 & 0.03 & 0.044 \\
Age at conception & 0.11 & 0.04 & 0.045 \\
Calving interval & 0.22 & 0.43 & 0.071 \\
Days open & 0.22 & 0.42 & 0.076 \\
Days to first service & 0.10 & 0.32 & 0.043 \\
Service period & 0.10 & 0.09 & 0.008 \\
\hline
\end{tabular}

${ }^{1}$ see Table 1 
Days open and calving interval showed genetic correlations ( 0.42 and 0.43 , respectively) with protein yield. Lower correlations were obtained for days to first service (0.32). Genetic correlations between protein yield and age at first service and age at conception were near zero. Genetic correlations between protein yield and non-return rates were negative and very small.

\section{Phenotypic and genetic correlations between content and fertility traits}

Phenotypic correlations between fat and protein content and fertility traits were very low (Tables 5 and 6). The highest (0.09) was found between protein content and age at conception; slightly lower phenotypic correlations were obtained for fat content with age at conception and service period (0.06). All remaining correlations were close to 0 .

Table 5. Genetic $\left(\mathrm{r}_{\mathrm{g}}\right.$ ) and phenotypic $\left(\mathrm{r}_{\mathrm{p}}\right.$ ) correlations between fat content and fertility traits and standard errors of the genetic correlations (SE)

\begin{tabular}{lccc}
\hline Trait & $\mathrm{r}_{\mathrm{p}}$ & $\mathrm{r}_{\mathrm{g}}$ & $\mathrm{SE}$ \\
\hline $\mathrm{NR}^{1} 56$ & -0.01 & -0.55 & 0.090 \\
$\mathrm{NR}^{1} 72$ & -0.02 & -0.27 & 0.043 \\
Age at first insemination & 0.04 & 0.14 & 0.005 \\
Age at conception & 0.06 & 0.14 & 0.006 \\
Calving interval & -0.01 & -0.15 & 0.012 \\
Days open & -0.01 & -0.12 & 0.010 \\
Days to first service & 0.00 & -0.05 & 0.009 \\
Service period & 0.06 & 0.09 & 0.009 \\
\hline
\end{tabular}

${ }^{1}$ see Table 1

Table 6. Genetic $\left(r_{\mathrm{g}}\right)$ and phenotypic $\left(\mathrm{r}_{\mathrm{p}}\right)$ correlations between protein content and fertility traits and standard errors of the genetic correlations (SE)

\begin{tabular}{lccc}
\hline Trait & $\mathrm{r}_{\mathrm{p}}$ & $\mathrm{r}_{\mathrm{g}}$ & $\mathrm{SE}$ \\
\hline $\mathrm{NR}^{1} 56$ & -0.02 & -0.41 & 0.150 \\
$\mathrm{NR}^{1} 72$ & -0.02 & -0.24 & 0.082 \\
Age at first insemination & 0.04 & 0.10 & 0.010 \\
Age at conception & 0.09 & 0.11 & 0.006 \\
Calving interval & -0.01 & -0.07 & 0.006 \\
Days open & -0.01 & -0.07 & 0.005 \\
Days to first service & 0.00 & -0.04 & 0.009 \\
Service period & 0.03 & -0.06 & 0.002 \\
\hline
\end{tabular}

${ }^{1}$ see Table 1

The highest genetic correlations between fat content and fertility traits were obtained for NR56 (-0.55) and NR72 (-0.27). Correlations with days open calving interval and age 
at conception were also negative but much lower. Low positive correlations were found for age at first insemination and age at conception $(0.14)$ and for service period $(0.09)$. Protein content was also genetically, negatively correlated with both NR56 (-0.41) and NR72 (-0.24). Genetic correlations between protein content and interval traits were negative and very small (less than 0.1 ). The correlations with age at first insemination and age at conception were positive and low ( 0.10 and 0.11 , respectively).

\section{DISCUSSION}

\section{Correlations between heifer fertility and yield traits}

Positive phenotypic correlations between yield and age at first insemination or age at conception are unfavourable because high-yielding cows conceive later. The phenotypic and genetic correlations between yield and age at first insemination and age at conception estimated in this paper were positive (unfavourable) and low (0.06-0.13).

Non-return rates reflect the cow's ability to conceive and depend less on breeder decisions than calving interval or days to first service. Despite low heritabilities, non-return rates are included in selection indexes in many countries. Nonreturn rate until day $90\left(\mathrm{~h}^{2}=0.02\right)$ is the only fertility trait evaluated in Germany (www.vit.de). Non-return rate as a measure of fertility is affected by different effects like age of the service sire or manner in which semen is processed. In fact, using non-return rate as the only measure leads to underestimation of fertility. In the Netherlands the fertility index consists of NR56 $\left(\mathrm{h}^{2}=0.015\right)$ and calving interval $\left(\mathrm{h}^{2}=0.058\right)$ (www.nrs.nl). In Canada, fertility index consisting of age at first service, heifer and cow non-return rates and interval from calving to first insemination has been introduced (Doormal et al., 2004). Currently, 11 countries or joint population take part in international test evaluations of fertility traits carried out by Interbull. In most of the countries non-return rate is evaluated together with some interval fertility traits or age at first insemination (Jorjani, 2005). Hertabilities of non-return rates in the population of Polish cattle are slightly lower than in the Netherlands (Jagusiak, 2005a), and the correlations between non-return rates and yield are low.

The phenotypic correlations between yield traits and non-return rates obtained in the current study were close to zero (from -0.01 to -0.1 ). Most phenotypic correlations reported in the literature are also low. Pryce et al. (1998) estimated unfavourable correlations between yield and conception to first service $(-0.12-$ -0.13). The correlations between production and number of services per conception estimated by Veerkamp et al. (2001) were also unfavourable and ranged from 0.10 for fat to 0.12 for protein yield. The same authors found low and 
negative phenotypic correlations between production and first-service conception: from -0.06 for milk yield to -0.07 for the remaining traits.

The genetic correlations between yield and NR56 obtained in this research ranged from -0.15 to -0.09 . The correlations between yield traits and conception to number of services estimated by Pryce et al. (1998) were also low (from -0.12 to -0.20$)$. Veerkamp et al. (2001) estimated moderate genetic correlations between production and number of services per conception ( 0.39 and more), and correlations between production and first service conception from -0.49 for milk to -0.51 for protein yield. Hansen et al. (1983) estimated large correlations between yield traits and number of services $(0.37-0.40)$

\section{Correlations between interval fertility and yield traits}

Number of days open is the most important part of the calving interval, because variation of gestation length, which is the second part of the calving interval, is very low (Jagusiak, 2005b). Therefore, estimates of the phenotypic and genetic correlations between calving interval and yield traits are usually similar to those between days open and yield traits. This relationship has been found in many papers (Campos et al., 1994; Veerkamp et al., 2001). Days to first service and service period are parts of the number of days open, and both depend on management that is, heat detection, health of the cow, feeding, etc. Estimates of heritabilities for interval fertility traits are higher than those for non-return rates (Jagusiak, 2005b), and genetic correlations with yield traits are moderate.

The phenotypic correlations between yield and interval traits estimated in this paper ranged from 0.10 to 0.22 , and showed that higher yield implied a longer interval. The phenotypic correlations of production traits obtained by Pryce et al. (1998) were moderate and unfavourable: 0.16-0.18 with calving interval, and 0.08-0.09 with days to first service. Veerkamp et al. (2001) estimated low correlations for calving interval (from 0.19 with milk to 0.16 with fat yield), for days open (0.20-0.17), and for days to first service (0.15-0.12).

Genetic correlations between yield and interval fertility traits were in general twice higher than phenotypic ones. The exception was length of service period, which showed small genetic correlations with yield traits. The genetic correlations between days open and milk yield traits reported by Hansen et al. (1983) were similar to those estimated in this paper, and ranged from 0.31 to 0.42 . Genetic correlations estimated by Pryce et al. (1998) were 0.28-0.53 for calving interval and 0.37-0.42 for days to first service. Campos et al. (1994) also found unfavourable genetic correlations between yield and fertility. The largest correlation for calving interval in Jerseys was estimated with fat yield (0.455), and the lowest with milk yield (0.162); a similar pattern was found for days open ( 0.355 and 0.268 , respectively). The genetic correlations between 
fat yield and fertility traits estimated by these authors in the population of Holsteins were lower than in Jerseys, and ranged from 0.201 for calving interval to 0.215 for days open. Oltenacu et al. (1991) obtained smaller genetic correlations between cumulative milk yield for first $100 \mathrm{~d}$ in milk with number of services per pregnancy. The correlations depended on the strain and age of the cows, and ranged from 0.09 to 0.13. Marti and Funk (1994) obtained a positive linear regression coefficient of days open on production. They investigated the relationship between production and fertility for different herd production levels and came to the conclusion that the highest-producing cows had the longest days open interval. The genetic correlations between production and interval fertility traits obtained by Veerkamp et al. (2001) were much higher than the respective phenotypic correlations. The correlations for days to first service ranged from 0.42 with fat to 0.53 with milk yield, for days open from 0.52 with fat to 0.61 with milk yield, and for calving interval from 0.58 with fat yield to 0.67 with the remaining traits.

\section{Correlations between fertility and content traits}

The phenotypic correlations between content and fertility traits were very low; the highest were those between age at conception and protein content (0.09). High antagonistic genetic correlations between non-return rates and fat and protein content showed that cows that conceived earlier tended to produce milk containing less fat and protein. Unfavourable small genetic correlations were also found for age at first insemination and age at conception. The correlations for interval traits were favourable but very small.

Positive and favourable relationships between fertility and environment may tend to improve phenotypic fertility in high-producing herds. However, the moderate unfavourable genetic correlations between milk production and fertility traits estimated in this paper as well as these reported by most cited authors show that selection for milk production must lead to decreased fertility in the long run. Selection for yield traits indirectly makes calving interval and days open longer, whereas selection for content traits indirectly reduces non-return rates. The differences in heritabilities and correlations between milk production and reproductive traits indicate that selection for better fertility should be based on a selection index including several interval and heifer fertility traits rather than one fertility measure.

\section{CONCLUSIONS}

The phenotypic correlations between milk production and fertility traits were antagonistic but low. The genetic correlations between yield traits and 
interval fertility traits were moderate, and the correlations between yield traits and non-return rates were close to zero. Large and moderate genetic correlations were found between content traits and fertility traits. The antagonistic genetic correlations between milk production and fertility traits show that selection for fertility is needed, and non-return rate as well as some interval fertility traits should be included in the overall selection index.

\section{REFERENCES}

Abdallah J.M., McDaniel B.T., 2000. Genetic change in milk, fat, days open and body weight after calving based on three methods of sire selection. J. Dairy Sci. 83, 1359-1363

Campos M.S., Wilcox C.J., Becerril C.M., Diz A., 1994. Genetic parameters for yield and reproductive traits of Holstein and Jersey cattle in Florida. J. Dairy Sci. 77, 867-873

Dematewewa C.M.B., Berger P.J., 1998. Genetic and phenotypic parameters for 305-day yield, fertility, and survival in Holsteins. J. Dairy Sci. 81, 2700-2709

Dodenhoff J., Van Vleck L.D., Kachman S.D., Koch R.M., 1998. Parameter estimates for direct, maternal, and grandmaternal genetic effects for birth weight and weaning weight in Hereford cattle. J. Anim. Sci. 76, 2521-2527

Hansen L.B., Freeman A.E., Berger P.J., 1983. Yield and fertility relationships in dairy cattle. J. Dairy Sci. 66, 293-305

Jagusiak W., 2005a. Fertility measures in Polish Black-and-White cattle. 1. Genetic parameters of heifer fertility traits. J. Anim. Feed. Sci. 14, 423-433

Jagusiak W., 2005b. Fertility measures in Polish Black-and-White cattle. 2. Genetic parameters of interval measures. J. Anim. Feed. Sci. 14, 435-444

Jorjani H., 2005. Interbull pilot study for female fertility traits in Holstein populations. Uppsala (Sweden), Interbull Bull. No. 33, pp. 34-44

Marti C.F., Funk D.A., 1994. Relationship between production and days open at different levels of herd production. J. Dairy Sci. 77, 1682-1690

Misztal I., Perez-Enciso M., 1993. Sparse matrix inversion for restricted maximum likelihood estimation of varince components by expectation-maximization. J. Dairy Sci. 76, 1479-1483

Nebel R.L., McGilliard M.L., 1993. Interactions of high milk yield and reproductive performance in dairy cows. J. Dairy Sci. 77, 3257-3268

Oltenacu P.A., Frick A., Lindhe B., 1991. Relationship of fertility to milk yield in Swedish cattle. J. Dairy Sci. 74, 264-268

Pryce J.E., Esslemont R.J., Thompson R., Veerkamp R.F., Kossaibati M.A., Simm G., 1998. Estimation of genetic parameters using health, fertility and production data from a management recording system for dairy cattle. Anim. Sci. 66, 577-584

Roxström A., Strandberg E., Berglund B., Emanuelson U., Philipsson J., 2001. Genetic and environmental correlation among female fertility traits and milk production in different parities of Swedish Red and White dairy cattle. Acta Agr. Scand., Sect. A., Anim. Sci. 51, 7-14

Veerkamp R.F., Koenen E.P.C., De Jong G., 2001. Genetic correlations among body condition score, yield, and fertility in first-parity cows estimated by random regression models. J. Dairy Sci. 84, 2327-2335

Westell R.A., Quaas R.L., Van Vleck L.D., 1988. Genetic groups in animal model. J. Dairy Sci. 71, 1310-1320

Windig J.J., Calus M.P.L., Veerkamp R.F., 2005. Influence of herd environment on health and fertility and their relationship with milk production. J. Dairy Sci. 88, 335-347 